\title{
Sociálne aspekty čitatel'skej gramotnosti s akcentom na diet’a zo sociálne znevýhodňujúceho prostredia na Slovensku
}

\author{
Vladimíra \\ Zemančíková
}

\section{Kontakt}

Univerzita Komenského

v Bratislave

Pedagogická fakulta

Moskovská 3

81108 Bratislava

Slovenská republika

zemancikova@fedu.uniba.sk

Korespondence:

zemancikova@fedu.uniba.sk

Copyright (C) 2021 by the author and publisher, TBU in Zlín.

This work is licensed under the Creative Commons Attribution International License (CC BY).

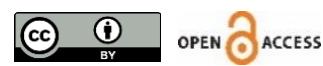

\begin{abstract}
Abstrakt: Čitatel'ská gramotnost' ako funkčná gramotnost', t. j. schopnost' porozumenia a používania písaných textov, je u žiakov zo znevýhodňujúceho prostredia na Slovensku alarmujúca. Slovenský vzdelávací systém vo vztáahu $\mathrm{k}$ detóm $\mathrm{z}$ menej priaznivého prostredia dlhodobo nedokáže primerane vyrovnávat' vzdelanostné nerovnosti determinované sociálnym pôvodom. Klúčové stimuly však pôsobia na deti ešte pred ich vstupom do základnej školy. $V$ štúdii sú predložené vybrané výskumy podpory detského čitatel'a $\mathrm{v}$ kontexte rodiny vychádzajúc z prevažne zahraničných zdrojov, kde má tento výskum bohatú tradíciu. Ako zvlášt́ významné boli identifikované faktory tzv. gramotného prostredia rodiny, osobitne spoločného čítania či tzv. dialogického čítania rodiča s dietatóm a vel'kosti rodinnej knižnice. $V$ závere príspevku sú načrtnuté možnosti sociálno-pedagogickej intervencie v predmetnej oblasti.
\end{abstract}

Klíčová slova: čitatel'ská gramotnost', gramotné prostredie rodiny, dialogické čítanie, diet́a zo znevýhodňujúceho prostredia

\section{Social aspects of reading literacy with an emphasis on children from a socially disadvantaged environment in Slovakia}

\begin{abstract}
Reading literacy as functional literacy, i.e. the ability to understand and use written text, is alarming for students from disadvantaged backgrounds in Slovakia. In relation to children from less favourable backgrounds, the Slovak education system has long been unable to adequately compensate for educational inequalities determined by social origin. The most important stimuli affect children before they enter primary school. The study presents selected research on supporting child readers within the context of the family, based mainly on foreign sources, where this research has a rich tradition. Factors in the so-called home literacy environment, especially reading together or socalled dialogic reading of a parent with a child, as well as the size of the family library, were identified as particularly important. At the end of the paper, the possibilities of socio-pedagogical intervention are outlined.
\end{abstract}

Keywords: reading literacy, home literacy environment, dialogic reading, socially disadvantaged children 


\section{1 Úvod}

V programovom vyhlásení vlády MŠ SR je v súvislosti so školskou politikou deklarovaná vzdelanost' občanov ako základný a nevyhnutný predpoklad jej dlhodobej existencie a prosperity. Avšak, ako súčasne uvádza tento dokument, podla analýz OECD úroveň slovenského školstva vo viacerých ukazovatel'och prepadáva na koniec európskeho rebrička. A medzi rozhodujúce oblasti, kde slovenské školstvo potrebuje významne napredovat', patria (okrem iného) výsledky žiakov $v$ čitatel'skej gramotnosti a vzdelávanie detí zo sociálne znevýhodňujúceho prostredia (MINEDU SK, n.d.). Slovenský národný program rozvoja výchovy a vzdelávania 2018-2027 (MINEDU SK, n.d.) zarad'uje medzi navrhované opatrenia v regionálnom školstve aj podporu čitatel'skej gramotnosti. Osobitne sa venuje otázke integrácie marginalizovaných detí zo sociálne-znevýhodňujúceho prostredia a v časti nazvanej „Školstvo dostupné pre všetkých“ pomenúva viaceré oblasti podpory detí a žiakov zo sociálne znevýhodňujúceho prostredia, pričom cielom týchto opatrení je zabránit’ predčasnému ukončeniu vzdelávania detí z marginalizovaných komunít (MINEDU SK, n.d.). Tento príspevok sa síce nevenuje školskej kompenzačnej edukácii detí z menej podnetného prostredia, je však vovedením do témy ranej gramotnosti tejto skupiny znevýhodnených detí, ktorá zohráva zásadnú úlohu v ich počiatočnom, ale aj neskoršom období školskej kariéry. Podpora detí a žiakov zo sociálne znevýhodńujúceho prostredia v školách má tak vychádzat' zo znalostí osobitostí a špecifík podmienok, v ktorých sa raná gramotnost' detí pochádzajúcich z menej priaznivého sociálno-ekonomického prostredia utvára. Na uvedené chce poukázat' tento príspevok.

Aktívne detské čitatel'stvo, primeraná úroveň čitatel'skej gramotnosti je jedným z faktorov vyrovnávajúcich vzdelanostné nerovnosti potomkov rodín odlišných sociálno-ekonomických vrstiev. Sociálne okolie dietatáa zohráva v tomto klúčovú úlohu, lebo čítanie nie je „osamelou“ činnostou, ako uvádza Garbe (2008), práve naopak - vývin stabilného čitatel'stva je závislý od podporných sociálnych a komunikačných kontextov, t.j. od osobných vztáahov. Pričom v detstve je týmto kontextom predovšetkým rodina, najčastejšie zastúpená postavou matky, neskôr i d'alšími osobami z okolia dietatata, a skúsenost́ dietatáa s tzv. sprostredkovaným učením.

Pre vývin „čitatel'a/čitatel'ky“ sú rozhodujúce zvlášt́ dve kritické fázy (Graf, 1995), pri ktorých je budovanie stabilnej motivácie $k$ čítaniu odkázané na vonkajšie podporné kontexty. Graf ich pomenúva ako „primárnu“ a „sekundárnu literárnu iniciáciu“. Pričom primárny vstup do sveta kníh nastáva $v$ období raného detstva, ešte pred začatím povinnej školskej dochádzky. A tu rodina, prevažne v osobe matky, umožňuje dietatúu skúsenost' s ponorením sa do verbálne sprostredkovaných fiktívnych svetov. Efekt spočiva v tom, že predčítanie alebo spoločné čítanie je viazané na intímne komunikačné situácie a realizuje sa cez emocionálny vztáa rodiča a dietáata, čo predstavuje pre diet́a zdroj intenzívneho pozitívneho zážitku sknihou. Sekundárna čitatel'ská iniciácia je spájaná s inštitúciou školy, kde rozhodujúce impulzy pre vztáah ku knihe prichádzajú zvlášt́ od učitel'ov či literatúry.

$\checkmark$ tomto texte nazrieme cez vybrané realizované výskumy na faktory vývinu detského čitatela, a to $v$ kontexte inštitúcie rodiny so zvláštnym akcentom na dietáa pochádzajúce z menej stimulujúceho rodinného prostredia. Nepopieratel'ný podiel v podpore detského čitatel'stva má i škola a vo vztahu $k$ detóm zo znevýhodňujúceho prostredia zvlášt jej kompenzačné intervencie - uvedeného sa v tomto príspevku dotýkame len okrajovo. Ciel'om tejto štúdie je analyzovat' vybrané aspekty gramotného prostredia rodiny a jeho dosahu na pregramotnostné schopnosti predškolského dietatáa a neskoršiu čitatel'skú gramotnost', a to s osobitým akcentom na deti pochádzajúce zo sociálne znevýhodňujúceho prostredia. Naším ciel'om je hl'adat' odpoved' na to, čo významné zistila literatúra o účinku gramotného prostredia rodiny na pregramotnostné a gramotnostné schopnosti jej potomkov. Na uvedený ciel'sme použili prehl'ad vybraných výsledkov výskumov na predmetnú tému, bližšie identifikovali zásadné faktory gramotného prostredia rodiny a na základe uvedeného načrtli intervenčné odporúčania do praxe. Zvolenými kritériami pre výber zdrojov do tejto prehl'adovej štúdie boli tieto: zvolené publikácie majú vplyv v príslušnom vedeckom poli, išlo teda prevažne o pravidelne citované výskumy inými 
autormi, preferovali sme štúdie autorov, ktorí v danej téme píšu frekventovane a sú citovaní inými autormi, kritériom tiež bolo, že išlo o zdroje prevažne založené na empirickom výskume.

\section{Vybrané teórie objasňujúce vzt́ah úrovne čitatel'skej gramotnosti a sociálno-ekonomického zázemia žiaka}

V uvádzajúcej kapitole stručne ponúkneme vybrané teoretické východiská vzt́ahu predčitatel'skej a čitatel'skej gramotnosti dietatáa vzhl'adom na podmienky rodinného prostredia. Zo svojej perspektívy naznačujú odpovede na otázky: Prečo rodičia detí zo znevýhodňujúceho prostredia patria častejšie do kategórie rodičov, ktorí nečítajú pravidelne svojim detom? Prečo je ich rodinná knižnica v priemere chudobnejšia? Prečo obdarúvajú svoje deti knihami zriedkavejšie, alebo aký je dôvod sporadickejšieho, prípadne žiadneho využívania knižničných služieb? Existujú rôzne teórie objasňujúce vzt́ah závislosti školskej úspešnosti diettat́a od jeho sociálneho pôvodu, tieto čiastočne súčasne ponúkajú odpoved'i na vyššie uvedené otázky súvisiace s gramotným prostredím rodín vo vztahu k čitatel'stvu detí. Stručne sa pristavíme pri jednotlivým teóriách.

Možnou príčinou slabších školských výkonov detí z nižších sociálnych vrstiev je ich nedostatočná skúsenost' so sprostredkovaným učením, ktorej následkom sú oslabené kognitívne funkcie. Feuerstein, predstavitel' teórie sprostredkovaného učenia a teórie štrukturálnej kognitívnej modifikovatel'nosti ${ }^{1}$, pripisuje $\mathrm{v}$ učebných situáciách zásadný význam druhým osobám v okolí dietatáa. Tieto významné druhé osoby učenie dietatúu sprostredkúvajú, a to tak, že vstúpia medzi podnetovú situáciu a diet́a a prispôsobia tak podnety jeho vývinovým potrebám (Feuerstein et al., 2006; Feuerstein, 2014). V praxi to potom znamená, že „dospelí napríklad vyberajú, zdôrazňujú... situácie, objekty, javy či procesy, ktoré sa $v$ životnom priestore dietatáa objavujú, alebo ich interpretujú" (Málková, 2009, s. 16). A takto je to aj v kontakte s knihou - rodičia vyberajú, ponúkajú, motivujú diet́a ku knihe, čítajú mu príbehy, rozprávajú sa o nich, zdôrazňujú významné obsahy, komentujú obrázky, pri otázkach detí odpovedajú... Nie každé dietáa však má dostatočne bohatú skúsenost' s takýmto sprostredkovaným učením. Deti bez dostatočnej skúsenosti sprostredkovaného učenia nedostávajú príležitost' učit' sa učit. Nežiaducim dôsledkom sú následne podla autora oslabené kognitívne funkcie². Za rozhodujúce je v súlade s touto teóriou považované sociálne okolie diet́ata, $t$. j. významní druhí. Nie všetci významní druhí ( $v$ prvom rade rodičia) vždy z objektívnych alebo subjektívnych dôvodov môžu, prípadne majú záujem poznanie sveta dietatúu sprostredkovávat'. Feuerstein uvádza, že rizikovými môžu byt spoločenské udalosti ako vojny, ale problém môže spočívat' aj v samotnej rodine. Rodina, ktorá je zat́ažená problémami, nie je schopná sprostredkovat' poznanie sveta dietatúu. Môže íst' o rodiny $v$ kríze partnerského spolužitia, ale často sem patria rodiny $v$ ekonomickej núdzi či rodiny sociálne vylúčené, kde rodičia v týchto prípadoch nie sú schopní citlivo vnímat' a adekvátne uspokojovat vývinové potreby dietatáa. Uvedené môže byt' spolupôsobiacim faktorom, prečo k aktívnemu kontaktu dietáata $s$ knihou $v$ sociálne znevýhodňujúcom prostredí rodiny dochádza $v$ priemere menej frekventovane. $V$ nasledujúcej teórii modelu rodinnej zát́aže ekonomickým nedostatkom, ktorú d’alej útržkom predstavíme, je podla nás objasnenie toho, prečo niektorí rodičia nie sú dostatočne zdatnými sprostredkovatel'mi poznania sveta pre svoje deti a teda prečo môžu mat́ niektoré deti menej stimulujúce kontakty s knihou.

1 Teória štrukturálnej kognitívnej modifikovatel'nosti predpokladá, že kognitívne schopnosti sú modifikovatel'né, t. j. je im vlastná dispozícia na zmenu, pričom prakticky ku kognitívnej modifikovatel'nosti možno dospiet' špecifickou formou interakcie medzi dietatom a skúsenejšou osobou, t. j. prostredníctvom sprostredkovaného učenia.

2 Oslabené kognitívne funkcie sú rozvíjatel'né. Pozitívnym aspektom danej teórie je to, že oslabené funkcie je možné stimulovat'. Feuerstein pre tento účel vytvoril program inštrumentálneho obohacovania, ktorý rozvíja učebný potenciál dietatáa, pričom aj v našom prostredí našiel bohaté uplatnenie (Feuerstein et al., 1988; Feuerstein, 2014). 
Teória rodinného modelu zát'aže ekonomickým nedostatkom³ (Barnett, 2008; Bradley \& Corwyn, 2002; Conger \& Donnellan, 2007; Dearing et al., 2001) pomenúva chudobu a nezamestnanost' ako negatívne faktory pôsobiace na rodinnú klímu, ktorá sa následne nepriaznivo odráža na vývin detí. $V$ centre tohto modelu stojí ekonomická dimenzia sociálno-ekonomického statusu rodiny. Model dáva do súvislosti nízke príjmy rodiny - predovšetkým dlhodobo pretrvávajúce finančné problémy s problémami vo vývine detí. Rodičia zatážení ekonomickým nedostatkom (Hoff et al., 2002) sú v dôsledku ekonomickej núdze pod vplyvom stresu. Každodenne prežívaná ekonomická núdza je pre dospelých v rodine natol'ko zatažujúca, že to má dosah na ich duševné rozpoloženie (napr. depresia), celkový zdravotný stav či vztáahy medzi manželmi (časté vzájomné konflikty). Uvedené sa negatívne odráža na ich rodičovských (výchovných) stratégiách, celkovo na zhoršenej starostlivosti o deti (Conger et al., 1992). Pričom nepriaznivý dopad na dieta je významnejší, ak je finančný nedostatok v rodine umocnený zlým stavom bytu, nevhodným miestom bývania, prítomný je nedostatok jedla, tepla. U rodičov je tak pod vplyvom následkov ekonomického nedostatku zvýšené riziko emočného napätia a následne títo vykazujú niektoré špecifické poruchy rodičovského správania. K takýmto prejavom patrí nedostatočné oceňovanie výchovných úspechov svojich detí, nedostatočná vzájomná komunikácia, matky s nižším sociálno-ekonomickým statusom sú direktívnejšie, prísnejšie a častejšie trestajúce. Takáto zátaž rodiča zmenšuje jeho rodičovské kapacity, rodičia sú následne prirodzene menej citliví na vývinové potreby diet'ata. A aké by mohli byt́ presahy zvýšeného emočného napätia rodičov $v$ rámci spoločného čítania $s$ dietatóm? Z vyššie uvedeného dôvodu môžu rodičia jednoducho v menšej miere siahat' pri interakcii $s$ dietatóm po knihe. Pričom samotná kvalita interakcie počas spoločného čítania môže byt́ menej uspokojivá, spoločné čítanie bude prebiehat́ pri menej priaznivej emočnej atmosfére. Rodič v tažšom duševnom rozpoložení má aktuálne menšie kapacity naladit' sa na diet́a a počas čítania naň citlivo reflektovat' a reagovat' a taktiež počas čítania potom vytvára menej priaznivú emocionálnu atmosféru, ktorá je klúčcovo potrebná pre umocnenie efektov prameniacich zo spoločného čítania.

Predchádzajúcej teórii je blízky model rodinných investícií (Becker \& Thomes, 1986; Bradley \& Corwyn, 2002), ktorý vidí zdroj vzdelanostných nerovností u detí odlišných sociálno-ekonomických tried vodlišnej miere rodičovských investícií do detí. Model vychádza z ekonomického princípu investovania, podla ktorého rodičia s vyšším SES (vyšším príjmom, vzdelaním a vyššou prestižou povolania) majú lepší prístup k finančnému, sociálnemu i l'udskému kapitálu. Investovanie týchto zdrojov rodinami je spojené s úspešným vývojom detí a dospievajúcich. Sociálno-ekonomické faktory pozitívne korelujú s mierou rodičovských investícií do detí a podla uvedeného títo rodičia s vyšším sociálno-ekonomickým statusom - v porovnaní s rodičmi zo znevýhodnených rodín - investujú do svojich detí viac zdrojov. "Investície do detí“ zahŕňajú rôzne dimenzie podpory detí rodičmi, ako napríklad dostupnost' učebných materiálov $v$ domácnosti ( $v$ súlade $s$ našou témou ide zvlášt' o knihy, ich množstvo, ale i obsahové zameranie či d'alšie tlačové materiály), podpora domácej prípravy detí, sprostredkovanie doučovania, patrí tu i životná úroveň rodiny v zmysle primeraného bývania, jedla, lekárskej starostlivosti, prístupu $\mathrm{k}$ dobrej škole, komunitné prostredie s dobrými zdrojmi pre rozvoj dietatáa (parky, ponuka aktivít v okolí pre deti). Podla tohto modelu potom ekonomický blahobyt súvisí s materiálnymi investíciami rodičov a d'alšími oblastami podporujúcimi rozvoj detí, čo sa následne odráža v miere ich akademického úspechu (Conger \& Donnelan, 2007). Tento model však, ako sme uviedli i vyššie, pomenúva okrem ekonomickej situácie rodiny taktiež význam výšky dosiahnutého vzdelania rodičov a ich profesijný status. Rodiny s vyšším sociálno-ekonomickým postavením investujú do detí viac peňazí, času, energie, súčasne kladú vyššie nároky na ich akademický úspech, jednoducho vytvárajú podnecujúcejšie prostredie. Z pohl'adu tejto témy tak možno predpokladat', že pôjde o rodičov, ktorí budú nakupovat' detom viac kníh, a to i odborného zamerania, budú si s nimi čítat' v častejšej frekvencii, navštevovat' spoločne knižnice, a ked'že ide o predstavitel'ov

3 Teória má svoje historické korene už vo výskumoch z obdobia vel'kej hospodárskej krízy, kde bolo potvrdené, že ekonomické problémy sa výrazne dotkli fungovania rodiny. V súlade s pokračujúcimi výskumami Conger a jeho kolegovia vyvinuli tento model, ktorým vysvetl'ujú, ako finančné problémy ovplyvňujú život v rodinách (Conger \& Conger, 2002). 
rodín s vyšším vzdelaním a vyšším profesijným statusom, možno zároveň predpokladat', že budú pre svojich potomkov i častejším modelom čítania.

V tejto súvislosti nemožno nespomenút známu teóriu kultúrneho kapitálu spojenú s menom Bourdieu. Bourdieu (Bourdieu \& Passeron, 1977) odpovedá na otázku slabšej školskej úspešnosti žiakov nižších sociálnych vrstiev prostredníctvom odlišnej úrovne zdedeného kultúrneho kapitálu po rodičoch, pričom autor (Bourdieu, 1986) rozlíšil tri oblasti kultúrneho kapitálu, a to vtelený, objektivizovaný a inštitucionalizovaný kultúrny kapitál ${ }^{4}$. Kultúrny kapitál úzko súvisí so životným štýlom rodiny, detom sprostredkúva vnímanie sveta, spôsoby myslenia či správania. Bourdieu síce výskumne preukázal rôznu úspešnost' študentov pochádzajúcich z odlišného sociálneho prostredia, avšak rozhodujúca (podla autora) pre mieru úspešnosti žiaka nie je vel'kost' majetku rodičov, ale vlastnosti sociálneho prostredia, ktoré s týmto postavením súvisia, ako je napríklad schopnost' vyjadrovat' sa požadovaným spôsobom, kultúrny rozhl'ad, štýl vystupovania, teda získané kultúrne dedičstvo po rodičoch (Keller \& Tvrdý, 2008). Aby sme lepšie prepojili tému nášho príspevku s teóriou kultúrneho kapitálu, osobitne spomenieme tzv. objektivizovaný kultúrny kapitál rodiny. Rozumieme ním kultúrne artefakty, vybavenie a materiálne zázemie rodiny kultúrnej povahy, pričom práve knihy, ich množstvo a obsahové zameranie rodinnej knižnice či knižnice dietatata tu zohráva klúčovú pozíciu ako východisko spoločných rodinných aktivít súvisiacich s čítaním (do objektivizovaného kultúrneho kapitálu patria i d'alšie artefakty, ako napr. umelecké obrazy, sochy, fotografie, hudobné nástroje...). Objektivizovaný kultúrny kapitál úzko súvisí s ekonomickým kapitálom a sociálnym postavením rodičov.

Jednotlivé teórie, ktoré sme tu stručne predstavili, ponúkajú teoretické východiská objasňujúce vztah sociálne znevýhodňujúceho postavenia dietatáa a jeho slabšej čitatel'skej gramotnosti. I ked' sa teórie osobitne nezaoberajú čisto čitatel'skou gramotnost'ou, ale všeobecne školskou úspešnostou dietatá, vychádzame z faktu, že čitatel'ská gramotnost' je klúčovým faktorom školskej úspešnosti. Predložené teórie si neprotirečia, vzájomne sa dopĺňajú a na problematiku nazerajú z inej perspektívy. Z nášho uhla pohladu sú predmetnej téme osobitne blízke prvé dve predstavené teórie, ktoré súvisia s istým „nastavením“ a motiváciou rodičov sprostredkovat' dietatúu „svet kníh“.

\section{3 Čitatel'ská gramotnost' detí zo sociálne znevýhodňujúceho prostredia na Slovensku - aktuálna situácia}

Už niekol'ko rokov medzinárodné komparatívne výskumy Programme for International Student Assessment (PISA; Miklovičová \& Valovič, 2019) a výskum Progress in International Reading Literacy Study (PIRLS; MINEDU SK, 2017) poukazujú na silnú závislost' výkonov žiakov (nielen) v oblasti čitatel'skej gramotnosti od ich sociálno-kultúrneho zázemia. A ako je známe, sila tejto závislosti však nie je v každej zo zapojených krajín rovnako intenzívna. Cyklus PISA 2009 bol užšie zameraný práve na čitatel'skú gramotnost' a priniesol pre Slovensko nelichotivé zistenia, čo sa týka silného vplyvu sociálneho pôvodu žiaka na jeho čitatel'skú kompetenciu. S odstupom rokov cyklus PISA 2018 bol opät' užšie zacielený práve na čitatel'skú gramotnost' a žial', podla výsledkov meraní je vplyv sociálnoekonomického zázemia slovenských žiakov na ich čitatel'skú kompetenciu v roku 2018 ešte silnejší, ako bol v roku 2009 (Miklovičová \& Valovič, 2019). Štúdia PIRLS (MINEDU SK, 2017), ktorá porovnáva čitatel'skú gramotnost' u žiakov 4. ročníkov ZŠ, taktiež potvrdila silnú závislost́ výkonu žiakov od ich sociálno-ekonomického a kultúrneho zázemia. Ked’že sa Slovenská republika zapája do štúdie PIRLS od jej prvého cyklu v roku 2001, možno výkony žiakov v čitatel'skej gramotnosti porovnávat' v priebehu 15 rokov a sledovat' tzv. trend výkonu, a to aj v špecifickej skupine, ktorou sú žiaci zo znevýhodňujúceho prostredia. Hoci priemerný výkon slovenských žiakov zostáva medzi cyklami PIRSL 2011 a 2016

4 Vtelený kultúrny kapitál sú intelektuálne a telesné dispozície človeka, získané v priebehu socializácie. Objektivizovaný kultúrny kapitál sú kultúrne artefakty využívané v domácnosti. Inštitucionalizovaný kultúrny kapitál predstavuje získané akademické tituly a vedecké hodnosti (Katrňák, 2004). 
nezmenený, výkon žiakov z rodín s málo zdrojmi ${ }^{5}$ sa oproti roku 2011 výrazne znízil. V tejto kategórii žiaci SR dosahujú najnižší výkon spomedzi zúčastnených krajín EÚ/OECD. Okrem uvedeného štúdia pomenovala významné aspekty školského a rodinného prostredia, ktoré výkon $v$ čítaní ovplyvňujú. Medzi tieto patria predškolské stimulujúce čitatel'ské aktivity v rodine, prítomnost' detí na predškolskej príprave, časté absencie na vyučovaní a taktiež pocit hladu pri príchode do školy ${ }^{6}$ (MINEDU SK, 2017). Z pohladu našej témy sú významné zistenia potvrdzujúce dosah predškolských stimulujúcich čitatel'ských aktivít, ktoré rodičia robia so svojimi det'mi, na ich neskorší výkon v čitatel'skej gramotnosti. Tak ako v predchádzajúcich cykloch, aj v PIRLS 2016 sa ukázal významný pozitívny vplyv takýchto rozvíjajúcich aktivít na čitatel'ský výkon žiaka. $O$ aké aktivity išlo? Čítanie kníh, rozprávanie príbehov, spievanie piesní, edukačné hry - hračky s abecedou, slovné hry, čítanie nahlas nápisov a názvov, písanie písmen... Podobne bola zistená súvislost' medzi vzt́ahom $\mathrm{k}$ čítaniu u rodičov a ich detí. Pričom vztáah rodičov k čítaniu súvisí aj s výkonom detí v čítaní - deti rodičov s negatívnym vztáahom $\mathrm{k}$ čitaniu dosiahli v priemere výrazne nižšie čitatel'ské skóre ako deti rodičov s pozitívnym vztahom k čítaniu. Zaujímavé bolo tiež zistenie o vztahu rodiča $\mathrm{k}$ čítaniu a frekvencii predškolských stimulujúcich aktivít, ktoré boli v prospech rodičov s pozitívnym vztáahom k čítaniu.

Mazáková a Dubayová (2012) porovnávali čitatel'skú gramotnost' slovenských žiakov druhých ročníkov základných škôl zo sociálne znevýhodňujúceho a intaktného prostredia a dospeli k očakávaným zisteniam, a to, že žiaci zo znevýhodňujúceho prostredia zaostávajú tak $v$ technike čítania, ako aj $\checkmark$ porozumení čítaného textu. Autorkami boli tiež identifikované spolupôsobiace faktory slabších čitatel'ských výkonov žiakov, ktorými sú častá absencia vzoru rodiča ako modelu čítania, neprítomnost' kníh a učebníc $v$ domácnosti, nízka návštevnost' knižníc a taktiež nedostatočný záujem rodičov o výsledky vzdelávania dietatáa. Nedostatočné porozumenie textu u rómskych žiakov z menej podnetného rodinného prostredia na Slovensku pomenoval i starší výskum Kmeta (2008), pričom ako autor uviedol, prekvapujúce boli výsledky získané v staršej skupine žiakov, u ktorých pretrváva čitatel'ská spôsobilost' sotva na úrovni čitatel'ských spôsobilostí o tri roky mladších žiakov z kontrolnej skupiny. I ked' technika čítania tejto skupiny žiakov je postupne zvládnutá, čítanie s porozumením ostáva podstatným problémom, pretože je základom školskej úspešnosti. Nácvik techniky čítania je, žial', v slovenskom školskom systéme dominantný, jeho nácvik zaberá vel'ký priestor na úkor sprostredkovávania efektívnych stratégií práce stextom podporujúcich čítanie s porozumením, a to s platnostou pre celú, nielen minoritnú skupinu žiakov (Humajová \& Klačanská, 2007).

Tieto zistenia sú odrazom dlhodobého problému neefektívneho vzdelávania detí zvlášt́ z marginalizovaných komunít s koncentrovanou chudobou. Školský vzdelávací systém na Slovensku nielenže dlhodobo nedostatočne vyrovnáva vstupné nerovnosti žiakov na počiatku ich vzdelávacej dráhy, ale aj vpriebehu d'alšieho vzdelávania žiakov dochádza k prehlbovaniu týchto rozdielov. Samozrejme, na problém nemožno nazerat' len cez prizmu "nedostatočne fungujúceho školstva“. Zhoršujúci sa problém nepriaznivej gramotnostnej situácie detí z marginalizovaných skupín je odrazom celospoločenských zmien, ktoré sa začali už v 90 . rokoch, kde zmeny v spoločenskej, politickej i sociálnej rovine mali a nad'alej majú nepriaznivý dosah na rozvrstvenie spoločnosti so znakmi stúpajúcich rozdielov $v$ sociálno-ekonomickej situácii rodín $s$ následným negatívnym dopadom na prehlbujúce sa vzdelanostné rozdiely. Zodpovednost' slovenského školstva však v tomto probléme neznižujeme, stojíme pred úlohou inšpirovat' sa vzormi iných úspešnejších krajín, u ktorých je

5 Žiaci s málo zdrojmi (SEl: sociálno-ekonomický index), ktorý opisuje sociálny, ekonomický a kultúrny kapitál rodiny. Pod zdrojmi domáceho prostredia rozumeli autori štúdie odpovede na otázky: počet kníh $v$ domácnosti, počet detských kníh, vzdelanie rodičov, dostupnost' materiálnych zdrojov - internetové pripojenie a vlastná izba, pričom pod rodinou s málo zdrojmi sa rozumie rodina s malým množstvom kníh, osobitne detských kníh, bez internetového pripojenia, s nižším vzdelaním rodičov (MINEDU SK, 2017).

6 Deti pochádzajúce zo sociálne znevýhodňujúceho prostredia, konkrétne prostredníctvom ukazovatela znevýhodnenia - pocitovaného hladu v škole - dosiahli v priemere výrazne nižší výkon v čitatel'skej schopnosti ako deti, ktoré pocitujú hlad len zriedka alebo nikdy. 
potvrdená nižšia závislost školskej úspešnosti (vrátane čitatel'skej gramotnosti) od sociálneho pôvodu dietatáa. Inšpirácie z iných krajín vzhladom na podporu inkluzívneho vzdelávania detí zo znevýhodňujúceho prostredia uvádza napr. Bakošová (2016).

\section{Rodina ako prominentný faktor čitatel'skej gramotnosti diet́at́a}

Prvá kritická fáza pre utváranie budúcej „čitatel'skej kariéry“ ako etapa primárnej literárnej iniciácie sa spája s potenciálom rodiny. Výskumy na poli čítania s bohatým zastúpením zvlášt́ v zahraničnej literatúre potvrdzujú tzv. Matúšov efekt (Matthew effect) ${ }^{7}$, podl'a ktorého je čítanie kumulatívnym procesom a úroveň tejto zručnosti je priamo úmerná prvotným impulzom od narodenia dietatá. Uvedené súvisí najmä s rozvojom slovnej zásoby detí, ktorým rodičia pravidelne čítali. Podla tohto efektu by sa mali interindividuálne rozdiely v čitatel'ských kompetenciách medzi slabými a normálnymi čitatel'mi s pribúdajúcimi rokmi ešte zväčšovat'. Tí, ktorým čítali viac, a tí, ktorí neskôr sami čítajú viac, sa stanú lepšími čitatel'mi. So zvýšenou intenzitou čítania sa schopnost' čítat' zlepšuje, čo na druhej strane viac podporuje samotné čítanie. Prejavuje sa tu kumulatívna, vývojová povaha čítania, jej kognitívny prínos, ktorý spočíva v tom, že čím viac je dietatatu čítané a neskôr čím viac samotné dieta číta, tým dosahuje lepšiu čitatel'skú kompetenciu. Efekt spočíva predovšetkým v náraste slovnej zásoby, ktorá umožní detom postupne zvládnut' i porozumenie náročnejším textom. Názov Matúšov efekt teda metaforicky odkazuje, že bohatí sa stávajú bohatšími a chudobní ešte chudobnejšími, čo platí i pre oblast' čitatel'stva (Bauerlein, 2007; Cunningham \& Stanovich, 1998; Pfost et al., 2011; Spitzer, 2012; Stanovich, 1986).

Uvedené pomenúva skutočnost', že schopnost' dobre čítat' sa formuje už dávno pred vstupom dietata do školy. V tejto súvislosti zaviedla Clayová (1966) do odbornej literatúry pojem vynárajúca sa gramotnost' (emergent literacy). Zásadný význam tu zohráva gramotné prostredie rodiny (home literacy enviroment). Rozumieme ním taký súbor podmienok v rodine, ktoré umožňujú dietatúu rozvoj jeho pregramotnostných schopností, pričom zvyčajne ide o vel'kost' a obsah rodinnej knižnice, dostupnost' tlačených materiálov, spoločné čítanie rodičov s dietatom, frekvencia a dížka čítania, návštevy knižníc a pod. Uvedené faktory priaznivo podporujú rozvoj jazykových kompetencií a gramotnosti dietáata (Bracken \& Fischel, 2008; Gavora, 2019; Martini \& Sénéchal, 2012). V zahraničí je množstvo výskumov k danej téme (napr. Burgess et al., 2002; Frijters et al., 2000; Griffin \& Morrison, 1997; Martini \& Sénéchal, 2012; Sénéchal \& LeFevre, 2002; Sénéchal, 2006,; Steensel, 2006), pričom zjednodušene platí, že čím je priaznivejšie gramotné prostredie rodiny, tým vytvára stimulujúcejšie podmienky pre budúcu úroveň č́tania svojich potomkov. Ak hovoríme o gramotnom prostredí rodiny, ide o množstvo faktorov, pričom nie všetky pôsobia na rozvoj pregramotnostných schopností rovnako. Aktivity v oblasti podpory pregramotnostných a gramotnostných schopností dietatáa možno rozdelit do dvoch odlišných typov rodičovských aktivít, a to na tzv. formálne a neformálne aktivity (Martini \& Sénéchal, 2012; Sénéchal, 2006). Najlepším príkladom neformálnych aktivít je podla autorky spoločné čítanie rodiča s diet́atom, pri ktorom sa rodič a diet́a zameriavajú na príbeh sprostredkovaný napísanými slovami. Naopak, činnosti formálnej gramotnosti sú tie, pri ktorých je pozornost' zameraná priamo na text, na tlačené slovo (napr. grafémy). Vo svojich longitudinálnych štúdiách Sénéchal a LeFevre (2002; Sénéchal, 2006) dokázali, že aktivity neformálnej gramotnosti sú väčšmi prepojené s ústnym jazykom, akým je napríklad získaná slovná zásoba dietatáa, zatial' čo interakcie s formálnou gramotnostou súviseli so schopnost́ami ranej gramotnosti, akými sú napríklad znalosti písmen (pričom znalost' písmen je jedným z prediktorov schopnosti čítania).

Úroveň gramotného prostredia rodiny je v úzkom vztahu so sociálno-ekonomickým statusom rodiny. $\mathrm{Na}$ otázku „Prečo sa chudobné deti pravdepodobne stanú chudobnými čitatel'mi?" sa pokúsili odpovedat' Buckinghamová, Beaman a Wheldall (2013), pričom predstavili prediktívnu cestu medzi

7 Podl'a evanjelistu Matúša „Lebo kto má, tomu sa pridá a bude mat' nadbytok. Kto však nemá, tomu vezmú aj to, čo má". 
sociálnym znevýhodnením a nedostatočnou ranou gramotnostou detí. U detí zo znevýhodnených rodín je vyššia pravdepodobnost', že charakteristiky gramotného rodinného prostredia budú menej priaznivé pre rozvoj klúčových prediktorov úspešného čitatela, akými sú napr. fonologické uvedomovanie, slovná zásoba, expresívna reč... Nižšia kvalita raných skúseností v súvislosti s gramotným prostredím rodiny následne zvyšuje riziko, že bude potlačený genetický potenciál dietatáa a diet'a bude mat' problém naučit sa primerane čítat. Navyše, tieto deti častejšie spadajú do kategórie detí so zdravotnými komplikáciami s negatívnym dosahom na ich kognitívne schopnosti, ako napr. predčasný pôrod, nízka pôrodná hmotnost', a okrem toho je u týchto detí o niečo nižšia pravdepodobnost' pravidelnej návštevy predškolského zariadenia (Buckingham et al., 2013).

Z výskumných zistení o význame gramotného prostredia rodiny vyberáme: vztah gramotného prostredia rodiny a jeho dopad na rozvoj gramotnosti dietata bol predmetom holandskej štúdie (Steensel, 2006). Autor v nej porovnával gramotné prostredie rodiny vo vztahu k sociálno-kultúrnym faktorom (etnický pôvod a sociálno-ekonomický status, d'alej SES). Podl'a očakávaní zistil, že holandské deti majority a deti z rodín s vysokým SES mali vo všeobecnosti najstimulačnejšie gramotné prostredie rodiny. Na druhej strane však bola pozorovaná značná variabilita gramotného rodinného prostredia $v$ rámci etnických menšín a rodín $s$ nízkym SES. Zo zistení tiež vyplynulo, že gramotné rodinné prostredie malo vplyv na slovnú zásobu detí v prvom ročníku a na ich schopnost ćítat' s porozumením v prvom aj druhom ročníku. Podobne Šormová (2016) v českom prostredí o čitatel'skej gramotnosti českých rómskych žiakov zistila očakávané rozdiely $v$ gramotnom rodinnom prostredí $v$ neprospech žiakov rómskeho pôvodu $v$ porovnaní so žiakmi majority. Rómski žiaci sa odlišovali od nerómskych zvlášt́ v nižšej dostupnosti kníh v domácnosti. Gramotné prostredie rodiny (dostupnost' kníh, predčítania rodičom, knihy ako darček...) sa ukázalo ako významný faktor čitatel'skej gramotnosti tak u rómskych, ako aj nerómskych žiakov. Z čoho vyplýva, že čím je priaznivejšie gramotné prostredie rodiny - nezávislé od etnicity -, tým žiaci dosahujú lepšie výsledky v testoch čitatel'skej gramotnosti. Podobne výsledky mad’arských autorov Kertesiho a Kézdiho (2013) napovedajú, že rozdiely vo výsledkoch rómskych a nerómskych žiakov základných škôl sú do vel'kej miery vysvetlitel'né sociálnym pozadím a zdá sa, že etnická príslušnost nezohráva podstatnú úlohu. Vplyv nepodnetného prostredia, horšej kvality vzdelávania v prvých ročníkoch na vývin gramotnosti rómskych detí potvrdili aj srbskí autori (Baucal, 2006).

Pozrime sa však bližšie na význam jednotlivých ukazovatel'ov gramotného prostredia rodiny na jazykový vývin detí z nízkopríjmových rodín. Americká štúdia (Whitehurst et al., 1994) gramotného prostredia rodín sa zamerala výhradne na deti z nízkopríjmových rodín ( $\mathrm{n}=323$ detí vo veku 4 rokov). Pričom východiskovým predpokladom autorov bolo, že u detí z chudobnejších rodín je obzvlášt́ pravdepodobnejšie, že budú mat́ nižšiu úroveň jazykových zručností, čo ich vystavuje väčšiemu riziku neskorších tážkostí s čítaním. Za ukazovatele gramotného prostredia rodiny bolo určené spoločné čítanie rodiča s dietatom, vek dietatáa, v ktorom si rodičia s dietatóm začali spoločne čítat', počet minút spoločného čítania v predošlom dni, počet obrázkových kníh v domácnosti, frekvencia žiadosti diet́ata o spoločné čítanie, frekvencia, akou si diet́a prezerá knihy samo, počet návštev knižnice rodiča $s$ dietatom, samotné čítanie rodiča a jeho pocit potešenia $z$ vlastného čítania. $Z$ výskumu vyplynulo, že nie všetky sledované premenné mali rovnako silný vplyv na jazykové kompetencie diet́ata ako prediktory čitatel'skej kompetencie. Nižšie korelácie boli namerané vo vzt́ahu medzi jazykovými kompetenciami dietatáa a vlastným čítaním rodičov. Zdá sa, že čas, ktorý primárni opatrovatelia trávia čítaním pre seba a pre vlastné potešenie z tohto čítania, má ovela menej priamy vplyv na jazykové kompetencie dietatáa. Podobne sa nepotvrdil silný vplyv frekvencie samostatného prezerania si kníh diet́atom a počet minút spoločného čítania s rodičom za predošlý deň. Ostatné ukazovatele, ako spoločné čítanie, počet detských kníh v domácnosti, spoločné návštevy knižníc sa preukázali ako významné v predmetnom vztahu. Možným vysvetlujúcim zdôvodnením korelačného vztáahu medzi jazykovými kompetenciami dietatáa a týmito ukazovatel'mi by mohlo byt vyššie IQ matky či jej vyššie vzdelanie. Avšak ako výsledky preukázali, samotné charakteristiky gramotného prostredia rodiny, nezávisle od inteligencie či výšky vzdelania matky zohrávajú významnú úlohu v úrovni raných jazykových kompetencií diet'atáa (Whitehurst et al., 1994). Zo sociálno-pedagogického hl'adiska v zmysle 
intervenčných stratégií sú tieto výsledky významné a ukazujú, ktorým smerom intervenovat' u rodín z nízkopríjmových skupín.

$\mathrm{K}$ najsilnejším faktorom $\mathrm{v}$ rámci gramotného prostredia rodiny patria spoločné čítanie rodičov $\mathrm{s}$ det'mi a dostupnost' kníh v rodine. Stručne sa pri týchto indikátoroch gramotného prostredia rodiny pristavíme. Význam spoločného čítania a interakcie medzi rodičom a dietatótom počas spoločného čítania na úroveň pregramotnostných schopností predškolského dietatata potvrdzuje štúdia Brackena a Fischela (2008), podla ktorých priaznivý dosah spoločného čítania prirodzene d'alej pokračuje i v období školských rokov dietatáa. Výskum lotyšských autorov (Geske \& Ozola, 2008) taktiež potvrdil, že čitatel'ská gramotnost' žiakov je ovplyvnená frekvenciou spoločného čítania rodičov s det́mi ešte v ich predškolskom veku. Scarborough, Dobrich a Hager (1991) takto porovnávali schopnost́ ćítania detí v 2. ročníku základnej školy a autori zistili, že deti, ktoré sa stali „chudobnejšími“ čitatel'mi, mali menej skúseností v predškolskom veku so spoločným čítaním s rodičom a vyznačovali sa tiež menším množstvom aktivít $s$ knihou $v$ domácom prostredí. Podobne podl'a správy medzinárodnej spoločnosti Scholastic (n.d.) deti, ktorým rodičia čítali v ranom detstve, sa naučili čítat' lahšie ako ich rovesníci, ktorým rodičia nečítali. To, či rodičia v ranom detstve detom čítali a či oni sami čítajú pre radost', patrí medzi silné prediktory budúceho vztáahu detí k čítaniu (Scholastic, n.d.). Vysvetlenie existencie vztáahu medzi frekvenciou spoločného čítania a úrovňou pregramotnostných a gramotnostných schopností detí objasnili Sénéchal, LeFevre, Hudson a Lawson (1996). Pričom autori pomenovali tri významné charakteristiky zdiel'aného čítania. Po prvé, jazyk používaný v knihách je zložitejší než jazyk, ktorý sa bežne používa počas bežnej konverzácie rodiča a dietatáa. Počas spoločného čítania tak môžu byt deti vystavené novým syntaktickým a gramatickým formám. Druhou črtou zdielaného čítania je, že dieta má sústredenú pozornost' dospelého, ktorý mu môže objasnit', vysvetlit', podporit' porozumenie čítaného a súčasne sprostredkuje poznanie nových znalostí. A tretou objasňujúcou charakteristikou významu spoločného čítania je, že knihy je možné čítat' aj opakovane, pričom opakovaná expozícia čítaného textu umožňuje osvojit' si receptívnu zložku slovnej zásoby.

Výskum v oblasti skorej čitatel'skej gramotnosti (early literacy) zistil, že nedostatok skúsenosti spoločného čítania je hlavne fatálny pre deti, ktoré vyrastajú v chudobnom podnetovom prostredí (Šedová \& Marcinová, 2020). Viaceré štúdie poukázali na to, že v rodinách s vysokými príjmami trávili rodičia viac času spoločným čítaním so svojimi det́mi (Bradley et al., 2001; Zick et al., 2001), prípadne matky z domácnosti s vyššími príjmami začínajú svojim detom čítat' v skoršom veku, pričom sa javí, že práve včasné zdielané čítanie má priaznivé dopady na neskoršie jazykové i kognitívne schopnosti diet'atáa (Karrass et al., 2003). V austrálskej longitudinálnej štúdii (Kalb \& van Ours, 2013) autori taktiež preukázali, že jedným z dôležitých faktorov, ktorý má vplyv na rozdiely $v$ čítaní a kognitívnych schopnostiach detí, je čítanie rodičov detom v útlom veku. Čitatel'ské spôsobilosti detí však nesúviseli s rodinným zázemím, ale s tým, ako často im rodičia čítali pred nástupom do školy. I ked' v priemere medzi rodičmi vzhl'adom na ich odlišnú sociálno-ekonomickú situáciu existujú vo frekvencii spoločného čítania rozdiely $\mathrm{v}$ neprospech nízkopríjmových rodín, $\mathrm{v}$ skupine rodičov $\mathrm{z}$ menej priaznivých ekonomických pomerov existuje vel'ká variabilita. Napr. Raikes at al. (2006) vo svojej štúdii zistili, že takmer polovica matiek z nízkoprijmových domácností si číta každý deň so svojimi det́mi. Podobne Malin, Cabrera a Rowe (2014) uvádzajú na základe svojho výskumu, že takmer 60 \% matiek (z ekonomicky menej priaznivého prostredia) si so svojimi det́mi čítajú raz alebo viackrát za deň. Takže vnútri skupiny detí pochádzajúcich z menej priaznivého prostredia existuje značná variabilita, čo sa týka frekvencie spoločného čítania a významným nie je len faktor frekvencie čítania.

Okrem toho, že sa na spoločné čítanie rodiča s diet’atom pozeráme zvonka, a to prevažne z hladiska jeho frekvencie či jeho včasného začatia, nemožno prehliadnut́ menej zachytitelný sprevádzajúci, ale o to význačnejší aspekt spoločného čítania, ktorým je emocionálne puto medzi rodičom a dietatom. Predčítanie alebo spoločné čítanie je viazané na intímne komunikačné situácie (napr. ako rituál na dobrú noc), realizuje sa cez emocionálny vztah rodiča a dietatáa a uvedené je pre dietá zdrojom intenzívneho pozitívneho zážitku s knihou. Dostávame sa tak trochu do inej roviny spoločného čítania, ale i táto emocionálna rovina súvisí v konečnom dôsledku s čitatel'skou gramotnostou dietatáa. $\mathrm{O}$ tom, 
že nielen frekvencia spoločného čítania rodiča s dietatom, ale i jeho kvalita, t. j. ako by mali rodičia $s$ dietatóm počas spoločného čítania interagovat' v zmysle podpory vztahovej väzby, a presahy uvedeného do ranej gramotnosti diet'at́a sú súčastou štúdie „Zdiel'ané čítanie knihy rodiča a dietatata, kvalita verzus kvantita čitatel'ských interakcií rodičov a malých detí (Kassov, 2006). Pri spoločnom čítaní rodiča a dietatáa ide teda o viac ako len jeho frekvenciu. Výskumy naznačujú, že nielen frekvencia čítania, ale aj kvalita čítania podporujú u detí slovnú zásobu (Deckner et al., 2006; Mol et al., 2008). Takto sa podl'a autoriek Baker, Scher a Mackler (1997) napríklad u detí, ktorých prvé stretnutia s gramotnostou boli zábavné, vyvinie predispozícia na častejšie čítanie. Pričom spoločné čítanie rozprávok zohráva dôležitú úlohu pri podpore motivácie k čítaniu. Autorky uvedené objasňujú tým, že ak je sociálno-emocionálna atmosféra počas spoločného čítania pozitívna, tak sa deti viac zaujímajú o čítanie a je pravdepodobnejšie, že ho budú vnímat aj ako zábavné. V súvislosti s uvedeným doplníme metaprieskum Clarka a Rumbolda (2006), ktorý poukázal na to, že čítanie pre zábavu je neskôr v živote pozitívne prepojené s porozumením textu, s rozšírením slovnej zásoby, s väčšou sebadôverou čitatela a s jeho radostou z čítania. Deckner et al. (2006) tiež uvádzajú, že deti, ktoré sú počas spoločného čítania pozorné, prežívajú radost' a zúčastňujú sa na čitatel'skej činnosti, inými slovami, prejavujú o čítanie záujem, sa častejšie učia nové slová ako deti, ktoré o čítanie nemajú záujem (Deckner et al., 2006).

A ako uvedené súvisí s det́mi zo znevýhodñujúceho prostredia? Ak si vezmeme do úvahy dieta $z$ chudobných rodinných pomerov, tak napríklad $v$ zmysle vyššie uvedenej teórie modelu zátaže rodiny ekonomickým nedostatkom môžeme predpokladat', že v interakcii medzi rodičom a dietatom počas ich spoločného čítania bude diet́a zažívat' menej často emočne priaznivú či zábavnú atmosféru a teda možno do istej miery predpokladat' podla vyššie uvedených výskumných zistení i menšie efekty vyplývajúce zo spoločného čítania na pregramotnostné schopnosti dietatáa.

V súvislosti so spoločným čítaním a iným aspektom „kvality“ spoločného čítania sa pristavíme ešte pri tzv. dialogickom/interaktívnom čítaní (dialogic reading), s ktorým majú v zahraničí mnohí rodičia praktické bohaté skúsenosti. Dialogické čítanie využíva súbor presne vymedzených postupov s cielom podporit slovnú zásobu dietatáa a súčasne podporit jeho schopnost́ počúvania s porozumením. Počas takého čítania zastáva diet́a aktívnejšiu rolu v porovnaní s tradičným čítaním, kde je v prevažujúcej pozícii počúvajúceho. Je to vedecky overená intervencia pri spoločnom čítaní rozprávkových kníh s potenciálom predchádzat alebo minimalizovat' neskoršie t'ažkosti dietatáa s čítaním. Pretože bohatost' slovnej zásoby má dosah na neskoršie osvojenie si schopnosti čítat', je vhodné túto metodiku používat' už od raného veku dietatáa, a zvlášt́ vhodná je v rizikových skupinách, ku ktorým z pohladu tohto textu patria i deti, ktoré v rodine hovoria iným jazykom ako v škole, a pre deti z domácností, v ktorých je diet́a písanému alebo hovorenému jazyku vystavené zriedkavejšie (Justice \& Pence, 2004). O prospešnosti dialogického čítania $v$ porovnaní $s$ tradičným čítaním na rozvoj expresívnej slovnej zásoby u detí vo zvlášt útlom veku (priemerný vek 13 mesiacov) referuje výskum autoriek Hargrave a Sénéchal (2000). Podobne metaanalýza šestnástich štúdií sledovala efekt tzv. dialogického (interaktívneho) čítania rodiča s diet'at'om predškolského veku na rozvoj jeho slovnej zásoby $\checkmark$ porovnaní s tzv. tradičným predčítaním. Metaanalýza potvrdila účinnost' dialogického čítania na rozvoj slovnej zásoby primárne u detí vo veku 3 až 4 rokov, pričom miera účinku sa podla výsledkov javila u starších detí (4-5) nižšia (Mol et al., 2008). V súvislosti s dialogickým čítaním sa ukazuje, že je potrebné rodičov k dialogickému čítaniu vzdelávat. Podla štúdie Huebnera a Payneho (2010) rodičia, ktorí prešli vzdelávaním dialogického čítania vo veku 2-3 rokov dietatata, pokračovali v jeho aplikácii i v neskoršom veku. Medzi odborníkmi sa však vynorila diskusia, či interaktívne spoločné čítanie kníh podporuje jazykové kompetencie detí rovnako efektívne vzhl'adom na ich rôzny sociálny pôvod. Napríklad výskum Manzovej et al. (2010) v USA naznačil, že deti z rodín s nižšími príjmami majú menší úžitok ( $v$ zmysle ich vynárajúcej sa gramotnosti) zo zdiel'aných intervencií počas spoločného čítania ako ich rovesníci z rodín s vyšším SES. Uvedené viedlo $k$ diskusii, či sú opatrovatelia s nižším SES potenciálne menej kompetentní implementovat' interaktívne prvky do spoločného čítania ako opatrovatelia s vyšším SES. Autori štúdie uvedené „menšie“ efekty interaktívneho čítania u detí zo znevýhodnených rodín vysvetl'ovali istým nesúladom medzi interaktívnym štýlom čítania vyučovaným v rámci danej 
metodiky a prirodzeným štýlom čítania u menej vzdelaných rodičov, ktorým jednoducho tento štýl čítania nie je natol'ko prirodzený. Avšak na rozdiel od uvedeného anglická štúdia (Noble et al., 2020), ktorá skúmala účinky interaktívneho čítania u 150 detí vo veku 2,6 až 3 roky rozdiely v poskytnutých intervenciách medzi rodičmi z odlišných socioekonomických tried nepotvrdila. Rodičia s nižším i vyšším SES implementovali intervencie interaktívneho čítania kníh rovnako efektívne (uvedené autori potvrdili prostredníctvom analýzy videozáznamov). Závery štúdie nepotvrdili nijaké dôkazy o tom, že opatrovatelia s nízkym SES sú menej schopní implementovat' interaktívne intervencie pri spoločnom čítaní kníh ako opatrovatelia s vyšším SES. Štúdia síce potvrdila efektívnost' „školenia“ rodičov v metodike interaktívneho čítania pre rodičov všetkých sociálno-ekonomických tried, prekvapujúco však nepreukázala významný vplyv na jazykové kompetencie detí. Príčinou uvedeného by mohlo byt', že intervenčný program trval len 6 týždňov, i ked' išlo o intenzívny stimulačný program, zachytitel'né priaznivé efekty na rozvoj jazykových zručností si podla nášho názoru vyžadujú dlhodobejšie intervencie.

Ak hovoríme o gramotnom prostredí rodiny ako o významnom faktore čitatel'skej úspešnosti dietatata, je potrebné ešte pre úplnost' doplnit', že schopnost' čítania je i „vecou génov“, na ktoré sa v tejto súvislosti niekedy zabúda. Individuálne rozdiely v čítaní sú spôsobené environmentálnymi faktormi, ale i genetickými rozdielmi, a súvislost' medzi gramotným prostredím rodiny a schopnostou dietata čítat' možno vysvetlit' aj premennou zdedených génov. Na uvedené upozorňuje výskum van Bergenovej, van Zuijenovej, Bishopovej a Jonga (2016), ktorého ciel'ovou skupinou boli holandskí rodičia a ich deti. Autori výskumu sa pýtali, či sú zodpovedné za schopnost' plynutého čítania detí environmentálne faktory (prostredie domácej gramotnosti - ako napr. frekvencia čítania, počet kníh v domácnosti, predplatené tlačoviny...) alebo genetické predispozície zdedené po rodičoch. Podla tejto štúdie sa ukázalo, že síce základné čitatel'ské schopnosti detí súvisia s niekol'kými aspektmi gramotného prostredia rodiny, ale mnohé sa javia ako tzv. maskované genetické efekty. Rodičia, ktorí ćítajú dobre, čítajú v priemere viac a sú vzdelanejší. Taktiež odovzdávajú det’om genetickú predispozíciu k dobrému čítaniu. Medzitým ich deti vyrastajú v rodine s vysokým SES, kde vidia svojich rodičov pravidelne čítat'. Takto majú deti vysoký predpoklad, že sa pravdepodobne stanú tiež dobrými čitatel'mi: podla autorov sa teda javí, že to nie je kvôli vzdelaniu rodičov a ich čitatel'ským návykom. Výnimkou sa však i podla tohto výskumu javí počet kníh, s ktorými deti vyrastajú, čo môže tiež mat' skutočný vplyv na úroveň čitatel'ských schopností detí. Z nášho pohl'adu sú tieto závery, ktoré pripisujú konečný význam z ukazovatel'ov gramotného prostredia rodiny len počtu kníh $v$ domácnosti, diskutabilné, a to i vzhladom na viaceré výsledky výskumov uvedených v predošlej časti textu.

Takto sa však dostávame $k$ druhému významnému indikátoru gramotného prostredia rodiny, a tým je dostupnost' kníh v domácnosti. Do tejto témy vstúpime myšlienkou Krashena (2011), podl'a ktorého dostupnost' vel'kej kolekcie atraktívnych kníh má potenciál naštartovat špirálu stúpajúcej motivácie, frekvencie čítania a porozumenia pri čítaní. Nepopieratelný význam rodinnej či osobnej knižnice dietatáa na jeho vztah k čítaniu či úrovni schopnosti čítat' potvrdili mnohé výskumy (napr. Cabanová \& Zemančíková, 2017; van Bergen et al., 2016). Bližšie stručne uvedieme výsledky slovenského výskumu, ktorý sme realizovali na Liptove. Jeho predmetom bola rodinná knižnica a knižnica diet'at́a vo vzt́ahu k školskej úspešnosti diet'at́a (Cabanová \& Zemančíková, 2017). Zistovali sme, aký dosah má na prospech žiaka rodinná knižnica, a to vzhl'adom na množstvo kníh, ktorými rodina disponuje, i na jej obsahové zameranie, t. j. podiel zábavnej, oddychovej, odbornej či populárno-náučnej literatúry. Samostatne bola braná na zretel' osobná knižnica diet'atáa. Zo zistení vyplynulo, že školská úspešnost́ žiaka na Liptove je vo významnom vzt́ahu s vel'kost'ou rodinnej knižnice, že významne väčší počet žiakov so slabým prospechom patrí do kategórie rodín s malým počtom kníh. Potvrdili sme tiež významné rozdiely $v$ obsahovom zameraní knižníc, pričom $v$ rodičovských knižniciach žiakov so slabým prospechom častejšie absentuje literatúra o umení, literatúra humanitných a spoločenských odborov, zemepisné mapy, atlasy či encyklopédie. Súčasne sme potvrdili, že nárastom množstva kníh v osobnej knižnici dietáata narastá podiel detí s výborným školským prospechom. 
Z výsledkov vyplynulo, že rodiny s rozsahovo i obsahovo bohatšou knižnicou vytvárajú svojim detom priaznivejšie podmienky pre ich školské napredovanie - a tak sme sa d'alej pýtali: $V$ čom sa odlišujú rodiny s bohatou knižnicou od rodín s chudobnou knižnicou. Potvrdili sme očakávania, že žiaci z rodín $s$ bohatšou rodinnou knižnicou majú častejšie aspoň jedného z rodičov s vysokoškolským vzdelaním a vyšším profesijným statusom, zároveň častejšie pochádzajú z vyššie príjmových domácností, pričom rozdiely sme potvrdili i v obsahovom zameraní knižnice. Podl'a Gabala a Václavíkovej Helšusovej (2003) pri kumulácii vyššieho príjmového, vzdelanostného a kultúrneho štandardu rodiny majú deti najvyššie šance dospiet' ku knihe a čítaniu, pričom za najsilnejší prvok sociálno-ekonomického zázemia rodiny z hl'adiska prístupu detí ku knihám označila dvojica autorov vzdelanie rodičov.

\section{Možnosti intervencie z pohl'adu sociálnej pedagogiky}

Ako sme uviedli v úvode, podla analýz OECD úroveň slovenského školstva v mnohých ukazovatel'och prepadáva na koniec európskeho rebríčka. A medzi rozhodujúce oblasti, kde slovenské školstvo potrebuje významne napredovat', je čitatel'ská gramotnost', a to predovšetkým u detí zo sociálne znevýhodñujúceho prostredia. $\vee$ predošlom texte sme poukázali na to, že zdroje tažkostí v oblasti čitatel'skej gramotnosti detí znevýhodnených skupín pramenia už z obdobia raného detstva a súvisia s gramotným prostredím rodiny, ktorý sa rozhodujúcou mierou podiela na pregramotnostných schopnostiach detí. Dickinson a Neuman (2006) zdôrazňujú, že podla výsledkov opakujúcich sa výskumov kritickou fázou, v ktorej deti „odvedú“ najväčší a rozhodujúci kus „kognitívnej práce“ na vývine gramotnosti, je vek od narodenia do šiestich rokov a že kvalita poskytnutých intervencií v tomto období je „životne dôležitá“, pretože zohráva klúčovú úlohu vich neskoršej školskej úspešnosti. $\mathrm{S}$ uvedeným rozhodne súhlasíme a v tomto smere vnímame zdroje v sociálno-pedagogickej intervencii $v$ práci s rodinou.

Európska výkonná agentúra pre vzdelanie, kultúru a audiovizuálnu oblast' (EACEA P9 Eurydice, 2011) v materiáli zameranom na rozvíjanie čitatel'skej gramotnosti konštatuje, že tvorcovia politík môžu zohrávat' podstatnú rolu, okrem iného napríklad aj prostredníctvom dotovania detských kníh a ich poskytovaním chudobnejším domácnostiam, ako aj tým, že budú podporovat' rodinné programy rozvíjajúce čitatel'skú gramotnost' detí, ktoré spočívajú predovšetkým v spoločnom čítaní (EACEA P9 Eurydice, 2011). V spomínanom dokumente je viacero príkladov takýchto programov, ktoré sú zacielené na rôzne populácie. Nejeden z programov vznikol ako reakcia na výsledky národných či medzinárodných prieskumov, ktoré zistili nedostatky v oblasti čitatel'skej gramotnosti (ako u nás napríklad výsledky PISA, PIRSL u žiakov zo znevýhodňujúceho prostredia). Konkrétnym príkladom takéhoto programu je slovinský program „Čítanie pre vedomosti a radost", v ktorom profesionálni mentori pomáhajú rodičom s nízkym vzdelaním a ich detom so vzdelávaním zameraným na gramotnost'. Práve $v$ takomto type programov vidíme priestor pre sociálno-edukačnú prácu so znevýhodnenými rodinami, pretože rozvoj čitatel'skej gramotnosti sa začína doma v rodine a deti z menej privilegovaných tried sú rizikové vzhl'adom na neraz iné menej stimulujúce podmienky gramotného prostredia ich rodín. Účinné rodičovské programy gramotnosti učia rodičov, ako si majú s det'mi čítat' v zmysle podpory ich pregramotnostných schopností.

Možnosti sociálno-pedagogickej intervencie spočívajú vo výchovno-vzdelávacej práci s rodičmi detí zo sociálne-znevýhodňujúceho prostredia, a to prostredníctvom sprostredkovania významu spoločného čítania pre d'alšiu úspešnost' dietatáa v živote, učenia rodičov efektívnym stratégiám spoločného čítania (t. j. čítanie v priaznivej emočnej atmosfére, pravidelné čítanie, čítanie dialogické, kde by dieta nezastávalo len pozíciu pasívneho poslucháča...) a stratégií utvárania návyku čítania u detí. V praxi by uvedené mohli realizovat' sociálni pedagógovia na pozíciách pracovníkov včasnej intervencie. Dnes sa vel'mi rozvíja oblast' včasnej intervencie prevažne smerom $\mathrm{k}$ detom s postihnutím a detóm s rizikovým vývinom. Túto myšlienku prakticky smerom $\mathrm{k}$ detom s rizikovým vývinom z marginalizovaných rómskych komunít na Slovensku uchopili do rúk členovia združenia Cesta von so svojím projektom Omama. Ďalšou praktickou možnostou, kde by mohli sociálni pedagógovia intervenovat' v zmysle 
podpory pregramotnostných schopností udetí v riziku, je pozícia odborných zamestnancov materských škôl, kde by mohli v spolupráci s rodičmi efektívne prepojit' v tomto smere výchovnú prácu materskej školy a rodiny.

\section{Záver}

Už niekol'ko rokov medzinárodné komparatívne výskumy (PISA, PIRLS) poukazujú na závislost' výkonov žiakov (nielen) v oblasti čitatel'skej gramotnosti od ich sociálno-kultúrneho zázemia, pričom tento vztáah závislosti je na Slovensku silný a s odstupom rokov ešte silnie. Uvedené zistenia sú odrazom dlhodobého problému nedostatkov vo vzdelávaní detí z marginalizovaných komunít s koncentrovanou chudobou a prehlbujúcich sa sociálnych nerovností v spoločnosti. Javí sa, že slovenský vzdelávací systém podla uvedeného aktuálne nedokáže dostatočne kompenzovat' vstupné nerovnosti žiakov a rozdiely medzi žiakmi odlišného sociálneho pôvodu sa v priebehu ich školskej kariéry ešte prehlbujú.

Programové vyhlásenie vlády MŠ SR vychádzajúc z analýz OECD uvádza, že úroveň slovenského školstva je vo viacerých ukazovatel'och na posledných priečkach „európskeho rebríčka", pričom čitatel'ská gramotnost' a vzdelávanie detí zo sociálne znevýhodňujúceho prostredia k týmto ukazovatel'om rozhodne patria. Slovenský národný program rozvoja výchovy a vzdelávania 2018-2027 (MINEDU SK, n.d.) k významným opatreniam regionálneho školstva zarad'uje podporu čitatel'skej gramotnosti a osobitne sa venuje otázke integrácie marginalizovaných detí zo sociálne znevýhodňujúceho prostredia, pričom zdôrazňuje nutnost' zabránit' ich predčasnému ukončeniu

Aktívne detské čitatel'stvo je významným faktorom školskej úspešnosti (nielen) žiakov marginalizovaných skupín. Je však závislé od existencie účinných vonkajších podporných mechanizmov, ktoré siahajú už do obdobia raného a predškolského veku. vzdelávacej cesty (MINEDU SK, n.d.). V tomto príspevku sme sa síce nevenovali otázke kompenzačnej edukácie detí marginalizovaných skupín, voviedli sme však čitatel'a do témy ranej gramotnosti ako východiska neskoršej školskej úspešnosti diet́ata pochádzajúceho zo sociálne znevýhodňujúceho prostredia.

Aktívne detské čitatel'stvo je jedným z faktorov podporujúcich vyrovnávanie vzdelanostných nerovností, pričom sociálne okolie diet'atáa zohráva v tomto klúčovú úlohu. A to preto, že budovanie motivácie k čítaniu je odkázané na vonkajšie podporné mechanizmy. Nemôžeme zabudnút, že vstup do sveta kníh sa začína ovela skôr ako povinná školská dochádza. Prvá kritická fáza pre utváranie budúcej „čitatel'skej kariéry“ sa spája s potenciálom rodiny. Výskumy na poli čítania s bohatým zastúpením zvlášt́ v zahraničnej literatúre potvrdzujú tzv. Matúšov efekt, podla ktorého je čítanie kumulatívnym procesom a úroveň čitatel'skej zručnosti je priamo úmerná prvotným impulzom od narodenia dietatáa, t. j. od akého veku, $v$ akej frekvencii alebo akým spôsobom si rodičia s dietatóm čítali. Podl'a tohto efektu by sa mali interindividuálne rozdiely $v$ čitatel'ských kompetenciách medzi slabými a normálnymi čitatel'mi s pribúdajúcimi rokmi ešte zväčšovat'. Práve tu zastáva nenahraditel'né miesto rodina. $\mathrm{V}$ texte sme predložili vybrané výskumy podpory detského čitatela $\mathrm{v}$ kontexte rodiny, pričom akcent bol kladený smerom $\mathrm{k}$ det́om zo znevýhodňujúceho prostredia. Predložený text poukázal na význam faktorov tzv. gramotného prostredia rodiny, pričom jeho úroveň, ako ukazujú mnohé výskumy, je v úzkom vztáahu so sociálno-ekonomickým statusom rodiny. U detí s menej priaznivým sociálno-ekonomickým zázemím sú charakteristiky gramotného prostredia menej podnecujúce raný jazykový vývin dietatáa. Nižšia kvalita raných skúseností v súvislosti s gramotným prostredím rodiny následne $v$ dôsledku oslabených jazykových zručností zvyšuje u dietatata riziko neskorších tážkostí s osvojovaním si čitatel'ských zručností. Ako sme v texte uviedli, ku klúčovým faktorom $v$ rámci gramotného prostredia rodiny patria spoločné čítanie rodičov $s$ det́mi a dostupnost' kníh v rodine. Výskumy voblasti skorej čitatel'skej gramotnosti zistili, že nedostatok skúsenosti 
spoločného čítania je hlavne fatálny pre deti vyrastajúce v chudobnom podnetovom prostredí. Okrem uvedeného rodiny týchto detí disponujú rozsahom i obsahom chudobnejšou rodinnou knižnicou. Javí sa, že kumuláciou vyššieho príjmového vzdelanostného a kultúrneho štandardu rodiny majú deti najvyššie šance dospiet' ku knihe a čítaniu, pričom uvedené platí i v opačnom význame.

V závere príspevku boli načrtnuté možnosti sociálno-pedagogickej intervencie v predmetnej problémovej oblasti. Kedže kvalita poskytnutých intervencií je zvlášt́ zásadná v období raného a predškolského veku dietatáa, navrhované intervencie smerovali do týchto vývinových fáz. Navrhované sociálno-pedagogické intervencie spočívajú v edukačnej práci s rodičmi detí zo znevýhodňujúceho prostredia prostredníctvom edukačných rodičovských programov, formou včasnej intervencie. $\checkmark$ predškolských zariadeniach prostredníctvom spolupráce materskej školy s rodinou dietata, kde vidíme možnosti predovšetkým v pozícii sociálnych pedagógov ako odborných zamestnancov predškolských zariadení.

\section{Prohlášení o střetu zájmů}

Autorka nezaznamenala žádný potenciální střet zájmů.

\section{Literatura}

Baker, L., Scher, D., \& Mackler, K. (1997) Home and family influences on motivations for reading. Educational Psychologist, 32(2), 69-82. https://doi.org/10.1207/s15326985ep3202_2

Bakošová, Z. (2016). Inclusion of children from the socially disadvantaged environment: The case study of Slovakia. Forum Scientiae Oeconomia, 4(2), 61-72.

Barnett, M. (2008). Economic disadvantage in complex family systems: Expansion of family stress models. Clinical Child and Family Psychology Review, 11(3), 145-161. https://doi.org/10.1007/s10567-008-0034-z

Baucal, A. (2006). Development of mathematical and language literacy among Roma students. Psihologija, 39(2), 207-227. https://doi.org/10.2298/PSI0602207B

Bauerlein, M. (2007). The dumbest generation. How the digital age stupefies young Americans and jeopardizes our future. Tarcher Perigee.

Becker, G., \& Tomes, N. (1986). Human capital and the rise and fall of families. Journal of Labor Economics, 4(3), 1-39.

Belešová, M. (2011). Žiakovo poňatie čítania a písania. In M. Bačová \& M. Černotová (Eds.), Zborník z medzinárodnej vedeckej elektronickej konferencie pre doktorandov, vedeckých pracovníkov a mladých vysokoškolských učitel'ov (s. 354-359). Katedra pedagogiky FHPV PU.

Bourdieu, P. (1986). The forms of capital. In J. Richardson (Ed.), Handbook of theory and research for the sociology of education (pp. 241-258). Greenwood.

Bourdieu, P., \& Passeron, J. (1977). Reproducion in education, society and culture. Sage publications.

Bracken, S. S., \& Fischel, J. E. (2008). Family reading behavior and early literacy skills in preschool children from low-income backrounds. Early Education and Development, 19(1), 45-67. https://doi.org/10.1080/10409280701838835

Bradley, R. H., \& Corwyn, R. F. (2002). Socioeconomic status and child development. Annual Review of Psychology, 53(1), 371-399. https://doi.org/10.1146/annurev.psych.53.100901.135233

Bradley, R. H., Corwyn, R. F., Burchinal, M., McAdoo, H. P., \& Coll, C. G. (2001). Home environments of children in the United States Part II: Relations with behavioral development through age thirteen. Child Development, 72(6), 1868-1886. https://doi.org/10.1111/1467-8624.t01-100383 
Buckingham, J., Beaman, R., \& Wheldall, K. (2013). Why poor children are more likely to become poor readers: The early years. Australian Journal of Education, 66(4), 428-446. https://doi.org/10.1080/00131911.2013.795129

Burgess, S. R., Hecht, S. A., \& Lonigan, C. J. (2002). Relations of the home literacy environment (HLE) to the development of reading-related abilities: A one-year longitudinal study. Reading Research Quarterly, 37(4), 408-426. https://doi.org/10.1598/RRQ.37.4.4

Cabanová, V., \& Zemančíková, V. (2017). Family libraries and school success of pupils. Psychology Research, 7(3), 154-163. https://doi.org/10.17265/2159-5542/2017.03.003

Clark, C., \& Rumbold, K. (2006, November). Reading for pleasure: A research overview. https://files.eric.ed.gov/fulltext/ED496343.pdf

Clay, M. (1966). Emergent reading behaviour [Unpublished doctoral dissertation]. University of Auckland.

Conger, R. D., \& Conger, K. J. (2002). Resilience in Midwestern families: Selected findings from the first decade of a prospective, longitudinal study. Journal of Marriage and Family, 64(2), 361-373. https://doi.org/10.1111/j.1741-3737.2002.00361.x

Conger, R. D., \& Donnellan, M. B. (2007). An interactionist perspective on the socioeconomic context of human development. Annual Review of Psychology, 58(1), 175-199. https://doi.org/10.1146/annurev.psych.58.110405.085551

Conger, R. D., Conger, K. J., Elder, G. H., Lorenz, F. O., Simons, R. L., \& Whitbeck, L. B. (1992). A family process model of economic hardship and adjustment of early adolescent boys. Child development, 63(3), 526-541. https://doi.org/10.1111/j.1467-8624.1992.tb01644.x

Cunningham, A. E., \& Stanovich, K. E. (1998). The impact of print exposure on word recognition. In J. L. Metsala \& L. C. Ehri (Eds.), Word recognition in beginning literacy (pp. 235-262). Lawrence Erlbaum Associates Publishers.

Dearing, E., McCartney, K., \& Taylor, B. A. (2001). Change in family in come-to-needs matters more for children with less. Child Development, 72(6), 1779-1793. https://doi.org/ 10.1111/14678624.00378

Deckner, D. F., Adamson, L. B., \& Bakeman, R. (2006). Child and maternal contributions to shared reading: Effects on language and literacy development. Journal of Applied Developmental Psychology, 27(1), 31-41. https://doi.org/10.1016/j.appdev.2005.12.001

Dickinson, D. K., \& Neuman, S. B. (2006). Handbook of early literacy research. Guilford Publications.

Disorders Quarterly, 25, 173-178. doi:10.1177/15257401040250040201

EACEA P9 Eurydice. (2011). Vyučovanie čítania v Európe: súvislosti, opatrenia a prax. https://doi.org/10.2797/66106

Feuerstein, R. (2014). Vytváření a zvyšování kognitivní modifikovatelnosti. Karolinum.

Feuerstein, R., Feuerstein, R. S., Falik, L., \& Rand, Y. (2006). Creating and enhancing cognitive modifiability: The Feuerstein Instrumental Enrichment Program, Part 1 Theoretical and conceptual foundations, Part 2, Practical applications of the Feuerstein Instrumental Enrichment Program. ICELP Publications.

Feuerstein, R., Rand, Y., \& Rynders, J. E. (1988). Don't accept me as I am: Helping "retarded" people to excel. Plenum Press.

Frijters, J. C., Barron, R. W., \& Brunello, M. (2000). Direct and mediated influences of home literacy and literacy interest on prereaders' oral vocabulary and early written language skill. Časopis pedagogickej psychológie, 92(3), 466-477. https://doi.org/10.1037/0022-0663.92.3.466 
Gabal, I., \& Václavíková Helšusová, L. (2003, květen). Jak čtou české děti? Analýza výsledků sociologického výzkumu. GAC. https://ipk.nkp.cz/docs/jakctouceskedeti.pdf

Garbe, C. H. (2008). Reading in Germany: Topical research results, background and concepts of reading support. In Z. Matušík (Ed.), Čtenarstvi, jeho význam a podpora. Vyzkum, teorie a praxe v České republice a Spolkové republice Nemecko (s. 5-19). Svaz knihovniku a informacnich pracovníku ČR.

Gavora, P. (2019). Stažená cesta ku gramotnosti: výskum rodičov, ktorí čítajú detom len sporadicky. Gramotnost, pregramotnost a vzdělávání, 3(1), 7-20.

Geske, A., \& Ozola, A. (2008). Factors influenc in greading literacy at the primary school. Problems of Education in the 21. Century, 6, 71-77. http://oaji.net/articles/2014/457-1392233338.pdf

Graf, W. (1995). Fiktionales Lesen und Lebensgeschichte. Lektürebiographien der Fernsehgeneration. In R. Rosebrock (Ed.), Lesen im Medienzeitalter (pp. 97-125). Juventa.

Griffin, E. A., \& Morrison, F. J. (1997). The unique contribution of home literacy enviroment to differences in early literacy skills. Early Child Development and Care, 127(1), 233-243. https://doi.org/10.1080/0300443971270119

Hargrave, A. C., \& Sénéchal, M. (2000). A book reading intervention with preschool children who have limited vocabularies: The benefits of regular reading and dialogic reading. Early Childhood Research Quarterly, 15(1), 75-90. https://doi.org/10.1016/\$0885-2006(99)00038-1

Hoff, E., Laursen, B., \& Tardif, T. (2002). Socioeconomic status and parenting. In M. H. Bornstein (Ed.), Handbook of parenting: Biology and ecology of parenting (pp. 231-252). Lawrence Erlbaum Associates Publishers.

Huebner, C. E., \& Payne, K. (2010). Home support for emergent literacy: Follow-up of a communitybased implementation of dialogic reading. Journal of Applied Developmental Psychology, 31(3), 195-201. https://doi.org/10.1016/j.appdev.2010.02.002

Humajová, Z., \& Klačanská, Z. (2007). Zabudnuté čítanie. Čitatel'ská gramotnost' v školách. Konzervatívny inštitút M. R. Štefánika.

Justice, L. M., \& Pence, K. (2004). Addressing the language and literacy needs of vulnerable children: Innovative strategies in the context of evidence-based practice. Communication, 25(4), 173180. https://doi.org/10.1177/15257401040250040201

Kalb, G., \& van Ours, J. C. (2013). Reading to young children: A head-start in life? Economics of Education Review, 40, 1-24. https://doi.org/10.1016/j.econedurev.2014.01.002

Karrass, J., VanDeventer, M. C., \& Braungart-Rieker, J. M. (2003). Predicting shared parent-child book reading in infancy. Journal of Family Psychology, 17(1), 134-146. https://doi.org/10.1037/08933200.17.1.134

Kassov, D. Z. (2006). Parent-child shared book reading: Quality versus quantity of reading interactions between parents and young children. Language and Communication, 1(1), 1-9.

Katrňák, T. (2004). Odsouzeni k manuální práci: vzdělanostní reprodukce v dělnické rodině. Slon.

Keller, J., \& Tvrdý, L. (2008). Vzdělanostní společnost? Chrám, výtah a pojištovna. Slon.

Kertesi G., \& Kézdi G. (2013). The achievement gap between Roma and non-Roma students in East Central Europe and its potential causes. GRINCOH.

Kmet', M. (2008, září 4-6). Čítajú rómsky žiaci s dostatočným porozumením? [Posterová prezentace]. Psychologické dny: Já \& my a oni, Olomouc. https://cmpsy.cz/files/pd/2008/pdf/kmet.pdf

Krashen, S. (2011). Free voluntary reading. Libraries Unlimited. 
Malin, J. L., Cabrera, N. J., \& Rowe, M. L. (2014). Low-income minority mothers' and fathers' reading and children's interest: Longitudinal contributions to children's receptive vocabulary skills. Early Childhood Research Quarterly, 29(4), 425-432. https://doi.org/10.1016/j.ecresq.2014.04.010

Málková, G. (2009). Sprostředkované učení. Portál.

Manz, P. H., Hughes, C., Barnabas, E., Bracaliello, C., \& Ginsburg-Block, M. (2010). A descriptive review and meta-analysis of family-based emergent literacy interventions: To what extent is the research applicable to low-income, ethnic-minority or linguistically-diverse young children? Early Childhood Research Quarterly, 25(4), 409-431. https://doi.org/10.1016/j.ecresq.2010.03.002

Martini, F., \& Sénéchal, M. (2012). Learning literacy skills at home: Parent teaching, expectations, and child interest. Canadian Journal of Behavioural Science / Revue canadienne des sciences du comportement, 44(3), 210-221. https://doi.org/10.1037/a0026758

Matoušek, O., \& Pazlarová, H. (2010). Hodnocení ohroženého dítěte a rodiny. Portál.

Mazáková, L., \& Dubayová, T. (2012). Čitatel'ská gramotnost' žiakov primárnej školy v kontexte sociálneho znevýhodnenia. In T. Dubayová \& Hrebeňárová, L. (Eds.), Študent na ceste k praxi. Zborník príspevkov z Prvej študentskej vedeckej konferencie $v$ odbore špeciálna a liečebná pedagogika (s. 136-145). Pedagogická fakulta Prešovskej univerzity v Prešove.

Miklovičová, J., \& Valovič, J. (2019). PISA 2018. Národná správa Slovensko. Národný ústav certifikovaných meraní vzdelávania. https://bit.ly/3EgHOcY

Ministerstvo školstva, vedy, výskumu a športu Slovenskej republiky (MINEDU SK). (2017, December 5). Prvé výsledky medzinárodného výskumu čitatel'skej gramotnosti žiakov štvrtého ročníka základných škôl - PIRLS 2016. https://www.minedu.sk/prve-vysledky-medzinarodnehovyskumu-citatelskej-gramotnosti-ziakov-stvrteho-rocnika-zakladnych-skol-pirls-2016/

Ministerstvo školstva, vedy, výskumu a športu Slovenskej republiky (MINEDU SK). (n.d.). Národný program rozvoja výchovy a vzdelávania 2018-2027. https://www.minedu.sk/data/att/13285.pdf

Ministerstvo školstva, vedy, výskumu a športu Slovenskej republiky (MINEDU SK). (n.d.). Školská politika. https://www.minedu.sk/data/att/10890.pdf

Mol, S. E., Bus, A. G., de Jong. M. T., \& Smeets, D. J. H. (2008). Added value of dialogic parent-child book readings: A meta-analysis. Early Education and Development, 19(1), 7-26. https://doi.org/10.1080/10409280701838603

Noble, C., Cameron-Faulkner, T., Jessop, A., Coates, A., Sawyer, H., Taylor-Ims, R., \& Rowland, C. F. (2020). The impact of interactive shared book reading on children's language skills: $A$ randomized controlled trial. Journal of Speech, Language, and Hearing Research, 63(6), 17871897. https://doi.org/10.1044/2020_JSLHR-19-00288

Pfost, M., Dörfler, T., \& Artelt, C. (2011). Reading competence development of poor readers in a German elementary school sample: An empirical examination of the Matthew effect model. Journal of Research in Reading, 35(4), 411-426. https://doi.org/10.1111/j.14679817.2010.01478.x

Raikes, H., Pan, B. A., Luze, G., Tamis-LeMonda, C. S., Brooks-Gunn, J., Constantine, J., Tarullo, L. B., Raikes, H. A., \& Rodriguez, E. T. (2006). Mother-child bookreading in low-income families: Correlates and outcomes during the first three years of life. Child Development, 77(4), 924-953. https://doi.org/10.1111/j.1467-8624.2006.00911.x

Scarborough, H. S., Dobrich, W., \& Hager, M. (1991). Preschool literacy experience and later reading achievement. Journal of Learning Disabilities, 24(8), 508-511. https://doi.org/10.1177/002221949102400811 
Sénéchal, M. (2006). Testing the Home Literacy Model: Parent Involvement in kindergarten is differentially related to grade 4 reading comprehension, fluency, spelling, and reading for pleasure. Scientific Studies of Reading, 10(1), 59-87. https://doi.org/10.1207/s1532799xssr1001_4

Sénéchal, M., \& LeFevre, J.-A. (2002). Parental involvement in the development of children's reading skill: A five-year longitudinal study. Child Development, 73(2), 445-460. https://doi.org/10.1111/1467-8624.00417

Sénéchal, M., LeFevre, J.-A., Hudson, E., \& Lawson, E. P. (1996). Knowledge of storybooks as a predictor of young children's vocabulary. Journal of Educational Psychology, 88(3), 520-536. https://doi.org/10.1037/0022-0663.88.3.520

Scholastic. (n.d.). Kids \& family reading report $7^{T H}$ edition. https://www.scholastic.com/readingreport/home.html

Spitzer, M. (2012). Digitale Demenz. Wie wir uns und unsere Kinder um den Verstand bringen. Droemer Verlag.

Stanovich K. E. (1986). Matthew effects in reading: Some consequences of individual differences in the acquisition of literacy. Reading Research Quarterly, 21(4), 360-407.

Steensel, R. V. (2006). Relations between socio-cultural factors, the home literacy environment and children'sliteracy development in the first years of primary education. Journal of Research Reading, 29(4), 367-382. https://doi.org/10.1111/j.1467-9817.2006.00301.x

Šedová, M., \& Marcinová, V. (2020). Ako pomôct' detóm, aby rady čítali. Technická univerzita v Košiciach.

Šormová, K. (2016). Jak čtou romové. Filozofická fakulta Univerzity Karlovy.

van Bergen, E., van Zuijen, T., Bishop, D., \& de Jong, P. F. (2016). Why are home literacy environment and children's reading skills associated? What parental skills reveal. Reading Research Quarterly, 52(2), 147-160. https://doi.org/10.1002/rrq.160

Whitehurst, G. J., Epstein, J. N., Angell, A. L., Payne, A. C., Crone, D. A., \& Fischel, J. E. (1994). Outcomes of an emergent literacy intervention in Head Start. Journal of Educational Psychology, 86(4), 542-555. https://doi.org/10.1037/0022-0663.86.4.542

Zick, C. D., Bryant, W. K., \& Österbacka, E. (2001). Mothers' employment, parental involvement, and the implications for intermediate child. Social Science Research, 30(1), 25-49. https://doi.org/10.1006/ssre.2000.0685

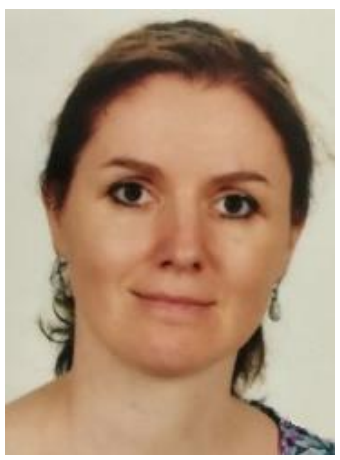

Mgr. Vladimíra Zemančíková, Ph.D. ukončila magisterské i doktorandské štúdium $v$ odbore pedagogika so špecializáciou sociálna pedagogika na Filozofickej fakulte Univerzity Komenského $v$ Bratislave, magisterské štúdium špeciálnej pedagogiky absolvovala na Univerzite Palackého v Olomouci. Od roku 2007 pôsobila na Katedre pedagogických štúdií Fakulty humanitných vied Žilinskej univerzity v Žiline, aktuálne pôsobí na Katedre pedagogiky a sociálnej pedagogiky Pedagogickej fakulty Univerzity Komenského v Bratislave. Vo vedeckovýskumnej činnosti sa venuje školskej sociálno-pedagogickej práci a užšie otázkam sociálne znevýhodňujúceho prostredia a jeho nežiaducim dopadom na jednotlivca. 